Jurnal PG-PAUD Trunojoyo : Jurnal Pendidikan dan Pembelajaran Anak Usia Dini, Volume 6, Nomor 2, Oktober 2019, hal $114-124$, ISSN : 2528-3553 (online), ISSN: 2407-4454 (print)

\title{
TINGKAT PENGETAHUAN GURU PAUD TENTANG KURIKULUM
} 2013

\author{
Dwi Noviana \\ Titin Faridatun Nisa' \\ Muhammad Busyro Karim \\ Program Studi Pendidikan Anak Usia Dini Universitas Trunojoyo Madura \\ Email:dwinoviana191@gmail.com, titinfaridatunnisa@trunojoyo.ac.id, busyrokarim.dz@gmail.com
}

Received (Bulan Juni 2019), Accepted (Bulan Agustus 2019), Bulan Oktober 2019)

\begin{abstract}
This quantitative-descriptive research describes knowledge level of Early Childhood Education teachers about 2013 curriculum in whole Pademawu kindergartens, Pamekasan regency. Requirement analysis tests use kolomogorov-smirnov normality test. The sample is taken by nonprobability sampling and purposive sampling, involving 73 Early Childhood Education teachers. Technique of collecting data are objective test in the form of true or false (T-F), interview, and documentation. Based on analysis, $\mathrm{HO}$ is denied and Ha is accepted in hypothesis test. Based on the findings, the knowledge level about 2013 curriculum in whole Pademawu kindergarten, Pamekasan is well, $87.71 \%$. Finding on remembering factor (C1) showed most of them were categorized well, 94.38\%; understanding (C2) categorized well, 85.57\%; and applying (C3) categorized well, $70.37 \%$. It can be concluded the knowledge level of the teachers about 2013 curriculum is well.
\end{abstract}

Keywords: Knowledge Level, Early Childhood Education Teachers, Curriculum 2013.

\begin{abstract}
Abstrak: Penelitian ini bertujuan untuk menggambarkan tingkat pengetahuan guru PAUD tentang kurikulum 2013 di TK Se-Kecamatan Pademawu Kabupaten Pamekasan. Metode dalam penelitian ini yaitu kuantitatif dengan pendekatan deskriptif. Adapun pengujian persyaratan analisis data dalam penelitian ini menggunakan uji normalitas kolmogorov-smirnov. Pengambilan sampel dalam penelitian ini menggunakan nonprobability sampling dengan teknik purposive sampling yaitu berjumlah 73 orang guru PAUD. Pengambilan data dalam penelitian ini menggunakan tes objektif dengan bentuk benar-salah (B-S), wawancara dan dokumentasi. Berdasarkan hasil perhitungan yang telah dilakukan dapat diketahui bahwa $\mathrm{H}_{-} 0$ ditolak dalam uji hipotesis. Hasil penelitian dapat diketahui bahwa tingkat pengetahuan guru PAUD tentang kurikulum 2013 di TK SeKecamatan Pademawu Kabupaten Pamekasan berada pada kategori baik dengan persentase sebesar 87,71\%. Hasil penelitian pada faktor mengingat (C1) sebagian besar berada pada kategori baik yaitu dengan persentase sebesar 94,38\%, menerapkan (C2) sebagian besar berada pada kategori baik yaitu sebesar 85,57\%, dan mengaplikasikan (C3) mengalami penurunan yaitu sebesar 70,37\%. Hasil penelitian tersebut disimpulkan bahwa Tingkat Pengetahuan Guru PAUD tentang Kurikulum 2013 di TK Se-Kecamatan Pademawu Kabupaten Pamekasan berada pada kategori baik.
\end{abstract}

Kata Kunci : Tingkat Pengetahuan, Guru PAUD, Kurikulum 2013

\section{PENDAHULUAN}

Pendidikan mempunyai peran yang sangat penting dan memiliki pengaruh terhadap proses dalam meningkatkan kemampuan daya saing negara tehadap negara lain. Pendidikan dapat disebut sebagai kunci keberhasilan dari sebuah negara, dan suatu bangsa dikatakan maju ditentukan oleh kemajuan dalam pendidikannya. Untuk mewujudkan hal tersebut, seseorang dapat menempuh jenjang pendidikan awal yaitu dimulai sejak PAUD.

Guru merupakan seseorang yang sangat berpengaruh terhadap pendidikan untuk meningkatkan kualitas dan mutu peserta didik menuju jenjang pendidikan yang lebih tinggi. Tanpa guru pendidikan menjadi suram bahkan tidak ada. Tidak heran jika dalam pepatah
Jawa mengatakan, guru merupakan sosok yang digugu omongane lan ditiru kelakuane (dipercaya ucapannya dan dicontoh ucapannya) (Suprahatiningrum, 2016: 16). Guru dianggap sebagai profesi yang sangat penting untuk mengoptimalkan pertumbuhan dan perkembangan peserta didik. Guru sebagai orang tua kedua saat di sekolah haruslah mempunyai pengetahuan dan keterampilan khusus untuk memberikan perubahan yang lebih baik lagi kedepannya untuk pertumbuhan dan perkembangan peserta didik. Oleh karena itu, peran guru PAUD dianggap sangat penting untuk mengoptimalkan seluruh potensi yang dimiliki peserta didik.

Seorang guru PAUD yang profesional sudah seharusnya memiliki kompetensi yang 
Jurnal PG-PAUD Trunojoyo : Jurnal Pendidikan dan Pembelajaran Anak Usia Dini, Volume 6, Nomor 2, Oktober 2019, hal 114 - 124, ISSN : 2528-3553 (online), ISSN: 2407-4454 (print)

melekat pada dirinya. Kompetensi tersebut terdiri dari kompetensi pedagogik, kompetensi kepribadian, kompetensi profesional dan kompetensi sosial (Permendikbud 137 Standar Nasional Pendidikan Anak Usia Dini, 2014: 54). Kompetensi pedagogik menuntut guru harus dapat mengorganisasikan kegiatan pembelajaran yang akan dilakukan berdasarkan kurikulum. Kompetensi pedagogik merupakan kemampuan seorang guru dalam penguasaan dan mengelola materi pembelajaran berdasarkan kurikulum yang berlaku serta bagaimana guru mengenal karakteristik masing-masing dari peserta didik. Maka dari itu, peran guru harus semaksimal mungkin agar perencanaan, pelaksanaan, penilaian dan evaluasi dalam pembelajaran berjalan dengan baik.

Guru harus memberikan pembelajaran sesuai dengan karakteristik dan perkembangan anak didik agar materi yang disampaikan dan didapat peserta didik dapat lebih baik. Sejalan dengan hal tersebut, Mulyasa berpendapat bahwa, "guru mempunyai tanggung jawab besar dalam bidang pendidikan. Selain tanggung jawab moral yang memberikan keteladanan, kemasyarakatan, dan keilmuan, guru juga harus menguasai cara belajar mengajar yang efektif, mampu mengembangkan kurikulum, silabus, dan rencana pembelajaran, melaksanakan pembelajaran yang efektif, menjadi model, memberikan nasihat, melaksanakan evaluasi hasil belajar, dan mengembangkan peserta didik" (Asmani, 2015: 71). Oleh karena itu, untuk mewujudkan tugas-tugas seorang guru pemerintah menyusun sebuah pedoman dan perangkat dalam pembelajaran yang disebut kurikulum.

Kurikulum adalah suatu hal yang penting dalam merancang sebuah pembelajaran. Adanya kurikulum membantu guru dan seluruh perangkat pendidikan untuk menyusun sebuah pembelajaran yang dapat membantu peserta didik untuk menjadi lebih baik lagi. Sebuah kurikulum mampu memberikan perubahan dalam pembelajaran agar kualitas pendidikan semakin meningkat. Kementerian Pendidikan dan menyatakan bahwa, dari tahun 1947 hingga tahun 2013, telah terjadi 11 kali perubahan terhadap kurikulum, mulai dari kurikulum pada zaman orde lama hingga saat ini (Suyadi \& Dahlia, 2017: 11). Perubahan kurikulum yang telah dilalui bukan tanpa alasan dan perubahan tersebut terjadi karena perkembangan zaman yang semakin meningkat.

Kurikulum yang digunakan di Indonesia yaitu Kurikulum 2013 yang dilaksanakan pada seluruh jenjang PAUD, SD, SMP, SMA, hingga SMK termasuk untuk Pendidikan Nonformal (Dirjen PAUD \& Pendidikan Masyarakat, 2015: 12). Hampir diseluruh Indonesia kurikulum 2013 telah diterapkan dan kesulitan-kesulitan yang dihadapi guru tentu ada. Kurikulum 2013 bisa jadi sulit untuk dilaksanakan di berbagai daerah karena sebagian besar guru belum siap (Mulyasa, 2015: 41). Kurikulum 2013 yang sampai saat ini menjadi sebuah perangkat yang harus dipelajari secara mendalam oleh guru khususnya untuk anak usia dini.

Struktur kurikulum pada semua jenjang berisi kompetensi inti dan kempetensi dasar. Kompetensi inti dan kompetensi dasar mencakup kompetensi sikap, pengetahuan dan keterampilan (Dirjen PAUD \& Pendidikan Masyarakat, 2015: 12). Kurikulum 2013 memberikan keunikan tersendiri di setiap jenjang termasuk Kurikulum 2013 untuk pendidikan anak usia dini. Pasalnya kurikulum 2013 PAUD lebih menuntut anak dalam mengoptimalkan enam aspek perkembangan yang meliputi nilai agama dan moral, fisik motorik, bahasa, sosial emosional, kognitif, serta seni dan kreativitas secara lebih mendalam. Selain itu, kurikulum 2013 memberikan pembelajaran yang tematik integratif dan penilaian auntentik serta peran orang tua dalam proses pembelajaran. Berkaitan dengan hal tersebut, "khusus kurikulum PAUD 2013, tidak ada perbedaan yang mendasar dari kurikulum sebelumnya. Justru kurikulum PAUD dengan ciri khas utama tematik-integratif dijadikan dasar bagi perubahan kurikulum pada jenjang SD/MI. Artinya, kurikulum PAUD selama ini dipandang masih relevan dengan perubahan zaman, terutana pembelajaran bermakna bagi anak didik" (Suyadi \& Dahlia, 2017: 11). Melalui kurikulum 2013 PAUD pemerintah berharap sangat besar adanya perubahan pendidikan khususnya untuk guru pendidikan anak usia dini agar mampu mengembangkan kurikulum 2013 dengan sebaik mungkin. Guru sebagai panutan peserta didik tentu harus mengetahui betul kriteria dan implementasi 
116 Jurnal PG-PAUD Trunojoyo : Jurnal Pendidikan dan Pembelajaran Anak Usia Dini, Volume 6, Nomor 2, Oktober 2019, hal 114 - 124, ISSN : 2528-3553 (online), ISSN: 2407-4454 (print)

dalam kurikulum 2013 pendidikan anak usia dini.

Peneliti menemukan saat melakukan observasi di lapangan, bahwa guru yang ada di Kecamatan Pademawu merasa kesulitan dengan adanya kurikulum 2013. Hal itu menuntut para guru untuk lebih mendalami tentang proses dan isi kurikulum 2013. Kondisi tersebut membuat guru tidak kondusif dalam memberikan pembelajaran di kelas dan lebih fokus pada kurikulum baru tersebut. Dengan adanya kondisi tersebut, peserta didik yang harusnya mendapatkan perhatian khusus untuk mengoptimalkan pertumbuhan dan perkembangannya menjadi tidak terealiasasikan. Beberapa TK yang ada di kecamatan Pademawu tidak menggunakan alat permainan edukatif atau media pembelajaran.

Saat peneliti melakukan wawancara dengan Ibu Nurmiyatik di TK Muslimat NU VII, setiap lembaga TK di Kecamatan Pademawu memiliki kesamaan Program Tahunan (Prota), Program Semester (Promes), Rencana Pelaksanaan Pembelajaran Mingguan (RPPM), Rencana Pelaksanaan Pembelajaran Harian (RPPH) dalam satu gugus yang membedakan hanyalah kegiatan. Hal tersebut peneliti ketahui berdasarkan dokumendokumen yang ada di lembaga TK seperti buku penilaian harian, RPPH, RPPM dan lain sebagainya. Dalam implemetasi kurikulum 2013 di TK Kecamatan Pademawu dirasa masih ada beberapa yang perlu mendapatkan perhatian. Kegiatan harian yang dilakukan sehari-hari baik diluar maupun di dalam kelas masih berbeda dengan RPPH. Maka dari itu, perbaikan pembelajaran perlu dilakukan demi mewujudkan tujuan pembelajaran yang sesungguhnya.

Beberapa TK di Kecamatan Pademawu masih ada yang baru menggunakan Kurikulum 2013 karena adanya akreditasi dari setiap lembaga, sehingga setiap TK berbondongbondong untuk memperbaiki kurikulumnya. Kesesuaian kurikulum 2013 dengan kompetensi guru masih kurang. Beberapa lembaga TK di kecamatan Pademawu masih ada yang memiliki sedikit peserta didik sehingga kelompok A dan kelompok B berada dalam satu kelas. Dalam hal itu, kegiatan yang diberikan oleh guru kepada anak sama dan tidak ada perbedaan antara kelompok A dan kelompok B. Padahal setiap anak memiliki kemampuan yang berbeda-beda.
Berdasarkan hasil wawancara awal yang telah dilakukan pada tanggal 11 Oktober 2018 kepada pengawas TK Se-Kecamatan Pademawu Kabupaten Pamekasan mengenai kurikulum 2013 yang telah diberlakukan sejak tahun 2014 di Kecamatan Pademawu, adanya ketidaksesuaian antara RPPH dengan implementasi di lapangan. Selain itu program tahunan, program semester, rencana pelaksanaan pembelajaran mingguan dan rencana pelaksanaan harian seharusnya guru yang membuat sendiri tetapi dalam kenyataannya satu gugus sama. Alat Permainan Edukatif (APE) atau alat peraga lain untuk pembelajaran di dalam kelas masih ada beberapa TK yang tidak menggunakannya, karena Lembar Kerja Anak (LKA) sudah dirasa cukup. Alumni atau lulusan guru TK di Se-Kecamatan Pademawu beberapa ada yang masih berijazah SMA dan sebagian juga ada yang sudah berijazah $S 1$, tetapi baik lulusan SMA maupun $\mathrm{S} 1$ yang belum memiliki ijazah PGPAUD melakukan studi lanjut.

Berdasarkan wawancara lanjutan pada tanggal 30 November 2018 dengan pengawas TK Se-Kecamatan Pademawu Kabupaten Pamekasan yaitu saat mengikuti diklat hanya perwakilan satu atau dua orang guru dari masing-masing TK. Dinas pendidikan memerintahkan demikian karena perwakilan yang datang dari setiap TK dapat menginformasikan apa yang didapat kepada teman yang berada pada satu TK. Setelah informasi yang disampaikan berdasarkan hasil diklat terkadang beberapa guru masih belum mengerti tentang apa yang telah disampaikan, hal tersebut dapat terjadi karena kemampuan guru yang berbeda dalam menyerap informasi. Beberapa diklat yang pernah dilakukan oleh pemerintah setempat untuk meningkatkan kuliatas pendidikan dan kemampuan guru seperti tentang Sosialisasi Kurikulum 2013, Pengembangan Kurikulum 2013, Proses Penilaian Kurikulum 2013, dan pada tanggal 7 Desember 2018 kemarin diadakan tentang Peningkatan Kinerja Guru.

Walaupun saat ini pemerintah terus memberikan penyuluhan, pelatihan kepada guru terkait kurikulum 2013 PAUD beberapa guru masih merasa bingung dengan adanya kurikulum 2013. Pengetahuan yang didapatkan setiap guru berbeda-beda sehingga membuat pengalaman yang didapatkan berbeda-beda pula. Penilaian tingkat pengetahuan dalam penelitian ini meliputi kemampuan guru dalam 
Jurnal PG-PAUD Trunojoyo : Jurnal Pendidikan dan Pembelajaran Anak Usia Dini, Volume 6, Nomor 2, Oktober 2019, hal 114 - 124, ISSN : 2528-3553 (online), ISSN: 2407-4454 (print)

kompetensi pedagogik yang pertama merancang kegiatan pengembangan anak usia dini berdasarkan kurikulum dan yang kedua menyelenggarakan dan membuat laporan penilaian, evaluasi proses dan hasil belajar anak usia dini.

Berdasarkan paparan tersebut, peneliti sangat tertarik untuk meneliti dan mengangkat judul "Tingkat Pengetahuan Guru PAUD tentang Kurikulum 2013 di TK se-Kecamatan Pademawu Kabupaten Pamekasan”.

\section{METODE}

Penelitian ini merupakan penelitian kuantitatif dengan pendekatan deskriptif. Metode penelitian kuantitatif diartikan sebagai metode postivistik karena berlandaskan pada filsafat positivisme, digunakan untuk meneliti populasi dan sampel tertentu (Sugiyono, 2015: 14). Penelitian deskriptif yakni penelitian untuk mendeskripsikan dan menjawab permasalahan suatu fenomena atau peristiwa yang terjadi, baik variabel tunggal, korelasi dan perbandingan berbagai variabel (Arifin, 2014: 54).

Berdasarkan teori tersebut, penelitian kuantitatif deskriptif merupakan data yang diperoleh dari populasi dan sampel penelitian yang telah ditentukan dan kemuadian dianalisis menggunakan metode statistika. Penelitian deskriptif dalam penelitian ini untuk menggambarkan tingkat pengetahuan guru PAUD tentang kurikulum 2013 di TK seKecamatan Pademawu Kabupaten Pamekasan.

Jumlah populasi dalam dalam penelitian ini sebanyak 242 orang guru PAUD di TK SeKecamatan Pademawu Kabupaten Pamekasan. Pengambilan sampel dalam penelitian ini menggunakan nonprobability sampling dengan teknik purposive sampling. Nonprobability sampling adalah teknik pengambilan sampel yang tidak memberikan peluang atau kesempatan sama bagi setiap unsur atau anggota populasi untuk dipilih menjadi sampel (Sugiyono, 2015: 122). Purposive sampling yakni suatu cara pengambilan sampel yang berdasarkan pada pertimbangan dan atau tujuan tertentu, serta berdasarkan ciri-ciri tertentu yang sudah diketahui sebelumnya oleh peneliti (Arifin, 2014: 221). Jika jumlah anggota populasi berada antara 101 orang sampai dengan 500 orang, maka sampel dapat diambil 30-40\% (Arifin, 2014: 221). Karena keterbatasan waktu dan biaya maka peneliti akan mengambil $30 \%$ dari populasi yaitu berjumlah 73 orang guru PAUD di TK sekecamatan Pademawu Kabupaten Pamekasan. Penggunaan sampel jenuh dikarenakan jumlah anak yang kurang dari 30.

Teknik pengumpulan data yang digunakan dalam penelitian ini berupa tes, wawancara dan dokumentasi. Dalam penelitian ini, soal tes akan menggunakan tes tertulis bentuk objektif. Tes objektif sering disebut tes dikotomi (dichotomously scored item) karena jawabannya antara benar dan salah dan skornya antara 1 sampai 0 (Arifin, 2016: 135). Tes objektif yang dipilih yaitu bentuk tes benar-salah (B-S) yang dapat digunakan responden untuk menentukan pilihannya mengenai pertanyaan-pertanyaan atau pernyataan-pernyataan dengan cara seperti yang diminta dalam petunjuk pengerjaan soal (Arifin, 2016: 135). Butir jawaban diberi skor dalam skala Guttman. Menurut Sugiyono, skala Guttman merupakan skala pengukuran dengan tipe jawaban yang akan didapatkan tegas yaitu antara "benar dan salah" atau "ya dan tidak" (Sugiyono, 2015: 139). Skala Guttman selain dibuat dalam bentuk pilihan ganda juga bisa dalam bentuk ceklis. Dalam penelitian ini, peneliti menggunakan pilihan ceklis dengan setiap butir jawaban dibuat skor tertinggi 1 dan terendah 0. Tes diberikan pada guru PAUD yang ada di TK Se-Kecamatan Pademawu Kabupaten Pamekasan sebanyak 73 orang. Penelitian ini menggunakan wawancara jenis

terstruktur. Wawancara terstruktur digunakan sebagai teknik pengumpulan data bila telah mengetahui dengan pasti tentang informasi yang akan peneliti peroleh (Sugiyono, 2015: 197). Wawancara dilakukan pada 5 orang guru yang berada di TK berbeda. Lembaga TK yang bersedia untuk diwawancarai yaitu TK Nurul Iman, TK Muslimat V, TK Dharmawanita Sumedangan, TK Kartika Bartim, dan TK Al-Quran Muballighin.

Tes sebelum digunakan dalam penelitian terlebih dahulu dilakukan validitas instrumen kepada dosen ahli. Setelah disetujui oleh dosen ahli akan diuji cobakan pada 10 orang responden yang memiliki karakteristik yang tidak jauh berbeda dengan kelompok sampel. Selanjutnya akan dilakukan uji validitas dan reliabilitas. Uji validitas menggunakan korelasi product moment. Uji coba dilakukan 
118 Jurnal PG-PAUD Trunojoyo : Jurnal Pendidikan dan Pembelajaran Anak Usia Dini, Volume 6, Nomor 2, Oktober 2019, hal 114 - 124, ISSN : 2528-3553 (online), ISSN: 2407-4454 (print)

pada 15 guru PAUD yang ada di Kecamatan Pamekasan. Lembaga yang dipilih peneliti yaitu TK PKK Bugih Pamekasan sebanyak 3 orang dan RA As-Sakinah Pamekasan sebanyak 7 orang. Hasil uji coba menunjukkan bahwa dari 32 soal terdapat 7 butir soal yang gugur yaitu nomor $12,13,15,20,25,26$ dan 30 , sehingga terdapat 25 butir soal valid. Penelitian ini menggunakan uji reliabilitas Spearman Brown karena tipe soal yang digunakan adalah tipe soal objektif. Perhitungan uji reliabilitas menggunakan rumus Spearman Brown teknik belah awal dan akhir. Berdasarkan perhitungan yang telah dilakukan, hasil uji reliabilitas sebesar 0,937. Nilai tersebut lebih dari 0,60 maka instrumen dinyatakan reliabel dan layak untuk digunakan sebagai penelitian. Sebelum menentukan analisis data yang akan digunakan dalam penelitian ini, peneliti terlebih dahulu melakukan uji prasyarat analisis dengan menggunakan uji normalitas.

Peneliti menggunakan uji normalitas kolmogorov-smirnov. Uji normalitas dengan uji kolmogorov-smirnov dilakukan apabila data merupakan data tunggal atau data frekuensi tunggal, bukan data distribusi frekuensi kelompok (Supardi, 2013: 129). Selain itu, sa mpel yang digunakan dalam penelitian ini yaitu lebih dari 30 orang.

Syarat uji normalitas menggunakan taraf signifikan $(\propto)$ yaitu 0,05 .

Hipotesis uji:

$\mathrm{H}_{0}$ : Data berdistribusi normal, melawan

$\mathrm{H}_{1}$ : Data tidak berdistribusi normal

Dengan kriteria pengujian:

Tolak $\mathrm{H}_{0}$ jika $\mathrm{a}_{\max }>\mathrm{D}_{\text {tabel }}$ dan

Terima $\mathrm{a}_{\max } \leq \mathrm{D}_{\text {tabel }}$

Penghitungan uji normalitas menggunakan bantuan SPSS 23 dan hasil dari a_max yaitu sebesar 0,010. Sampel yang digunakan oleh peneliti sebesar 73 sehingga D_tabel yaitu 0,16. Maka diperoleh $\mathrm{a}_{\max }$ $(0,010) \leq \mathrm{D}_{\text {tabel }} 0,16$ maka $\mathrm{H}_{0}$ diterima dan disimpulkan data berdistribusi normal.

\section{HASIL DAN PEMBAHASAN Hasil}

Penelitian ini yaitu Tingkat Pengetahuan Guru PAUD tentang Kurikulum 2013 di TK Se-Kecamatan Pademawu Kabupaten Pamekasan yang datanya diperoleh melalui penyebaran tes pengetahuan kepada 73 orang guru PAUD yang telah ditentukan dan tersebar di 15 lembaga TK Kecamatan Pademawu Kabupaten Pamekasan. Tes pengetahuan tersebut berupa pernyataan-pernyataan yang telah diuji validitas dan reliabilitasnya dengan jumlah 25 pernyataan.

Penelitian ini menggunakan lembar tes berupa benar dan salah dengan pernyataanpernyataan yang terdiri dari faktor mengingat (C1) sebanyak 10 butir pernyataan, faktor memahami (C2) sebanyak 7 butir pernyataan dan faktor menerapkan (C3) sebanyak 8 butir pernyataan. Jadi, jumlah keseluruhan pernyataan sebanyak 25 butir. Setiap butir jawaban diberi skor dalam skala Guttman dalam bentu ceklis dengan skor tertinggi 1 dan terendah 0 .

Hasil dari penelitian yang dilakukan oleh peneliti yang telah menyebarkan 73 lembar tes dengan seluruh butir pernyataan yaitu 24 kepada responden sebanyak 73 orang guru PAUD di TK Se-Kecamatan Pademawu Kabupaten Pamekasan diperoleh data dalam tabel 1 .

Tabel 1.

Deskripsi Hasil Tingkat Pengetahuan Guru PAUD tentang Kurikulum 2013 di TK SeKecamatan Pademawu Kabupaten Pamekasan

\begin{tabular}{|c|c|c|}
\hline No. Responden & $\begin{array}{c}\text { Jumlah } \\
\text { Jawaban Benar }\end{array}$ & $\begin{array}{c}\text { Persenta } \\
\text { Se (\%) }\end{array}$ \\
\hline Responden 1 & 21 & $84 \%$ \\
\hline Responden 2 & 20 & $80 \%$ \\
\hline Responden 3 & 22 & $88 \%$ \\
\hline Responden 4 & 21 & $84 \%$ \\
\hline Responden 5 & 21 & $84 \%$ \\
\hline Responden 6 & 22 & $88 \%$ \\
\hline Responden 7 & 20 & $80 \%$ \\
\hline Responden 8 & 20 & $80 \%$ \\
\hline Responden 9 & 22 & $88 \%$ \\
\hline Responden 10 & 20 & $80 \%$ \\
\hline Responden 11 & 20 & $80 \%$ \\
\hline Responden 12 & 22 & $88 \%$ \\
\hline Responden 13 & 21 & $84 \%$ \\
\hline Responden 14 & 20 & $80 \%$ \\
\hline Responden 15 & 20 & $80 \%$ \\
\hline Responden 16 & 25 & $100 \%$ \\
\hline Responden 17 & 24 & $96 \%$ \\
\hline Responden 18 & 22 & $88 \%$ \\
\hline Responden 19 & 24 & $96 \%$ \\
\hline
\end{tabular}


Jurnal PG-PAUD Trunojoyo : Jurnal Pendidikan dan Pembelajaran Anak Usia Dini, Volume 6, Nomor 2, Oktober 2019, hal 114 - 124, ISSN : 2528-3553 (online), ISSN: 2407-4454 (print)

\begin{tabular}{|c|c|c|}
\hline Responden 20 & 22 & $88 \%$ \\
\hline Responden 21 & 22 & $88 \%$ \\
\hline Responden 22 & 22 & $88 \%$ \\
\hline Responden 23 & 22 & $88 \%$ \\
\hline Responden 24 & 23 & $92 \%$ \\
\hline Responden 25 & 24 & $96 \%$ \\
\hline Responden 26 & 24 & $96 \%$ \\
\hline Responden 27 & 24 & $96 \%$ \\
\hline Responden 28 & 22 & $88 \%$ \\
\hline Responden 29 & 18 & $72 \%$ \\
\hline Responden 30 & 19 & $76 \%$ \\
\hline Responden 31 & 18 & $72 \%$ \\
\hline Responden 32 & 19 & $76 \%$ \\
\hline Responden 33 & 19 & $76 \%$ \\
\hline Responden 34 & 25 & $100 \%$ \\
\hline Responden 35 & 24 & $96 \%$ \\
\hline Responden 36 & 24 & $96 \%$ \\
\hline Responden 37 & 25 & $100 \%$ \\
\hline Responden 38 & 25 & $100 \%$ \\
\hline Responden 39 & 24 & $96 \%$ \\
\hline Responden 40 & 23 & $92 \%$ \\
\hline Responden 41 & 23 & $92 \%$ \\
\hline Responden 42 & 23 & $92 \%$ \\
\hline Responden 43 & 23 & $92 \%$ \\
\hline Responden 44 & 22 & $88 \%$ \\
\hline Responden 45 & 22 & $88 \%$ \\
\hline Responden 46 & 20 & $80 \%$ \\
\hline Responden 47 & 20 & $80 \%$ \\
\hline Responden 48 & 20 & $80 \%$ \\
\hline Responden 49 & 17 & $68 \%$ \\
\hline Responden 50 & 17 & $68 \%$ \\
\hline Responden 51 & 17 & $68 \%$ \\
\hline Responden 52 & 22 & $88 \%$ \\
\hline Responden 53 & 22 & $88 \%$ \\
\hline Responden 54 & 22 & $88 \%$ \\
\hline Responden 55 & 22 & $88 \%$ \\
\hline Responden 56 & 19 & $76 \%$ \\
\hline Responden 57 & 20 & $80 \%$ \\
\hline Responden 58 & 18 & $72 \%$ \\
\hline Responden 59 & 21 & $84 \%$ \\
\hline Responden 60 & 19 & $76 \%$ \\
\hline Responden 61 & 17 & $68 \%$ \\
\hline
\end{tabular}

\begin{tabular}{|c|l|l|}
\hline Responden 62 & 17 & $68 \%$ \\
\hline Responden 63 & 17 & $68 \%$ \\
\hline Responden 64 & 20 & $80 \%$ \\
\hline Responden 65 & 21 & $84 \%$ \\
\hline Responden 66 & 20 & $80 \%$ \\
\hline Responden 67 & 21 & $84 \%$ \\
\hline Responden 68 & 21 & $84 \%$ \\
\hline Responden 69 & 21 & $84 \%$ \\
\hline Responden 70 & 19 & $76 \%$ \\
\hline Responden 71 & 20 & $80 \%$ \\
\hline Responden 72 & 19 & $76 \%$ \\
\hline Responden 73 & 20 & $80 \%$ \\
\hline $\begin{array}{c}\text { Mean (Rata- } \\
\text { rata) }\end{array}$ & $\mathbf{2 1 , 0 5}$ \\
\hline Persentase & $\mathbf{8 7 , 7 1 \%}$ \\
\hline
\end{tabular}

Tinghat Pengetalusai Berdasarkan Fakter C1, C2 dan C3

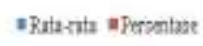

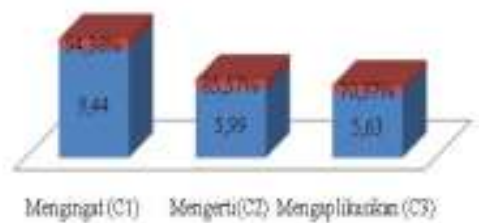

Gambar 1. Grafik Hasil Penelitian Tingkat Pengetahuan Berdasarkan Faktor C1, C2 dan $\mathrm{C} 3$

Berdasar tabel 1 diketahui bahwa tingkat pengetahuan guru PAUD tentang Kurikulum 2013 di TK Se-Kecamatan Pademawu Kabupaten Pamekasan rata-rata memperoleh nilai 21,05 dengan persentase sebesar $87,71 \%$ yang artinya termasuk pada kategori baik.

Hasil penelitian berdasarkan 73 responden dengan masing-masing responden 25 butir pernyataan yaitu mengingat (C1) sebanyak 10 butir pernyataan, mengerti (C2) sebanyak 7 butir pernyataan dan mengaplikasikan (C3) sebanyak 8 butir pernyataan dengan diperoleh data dalam bentuk grafik dapat dilihat pada gambar 1

Berdasarkan tabel 1 dan gambar 1 dapat diketahui bahwa tingkat pengetahuan guru PAUD tentang Kurikulum 2013 di TK SeKecamatan Pademawu Kabupaten Pamekasan berdasarkan $\mathrm{C} 1, \quad \mathrm{C} 2$ dan $\mathrm{C} 3$ rata-rata memperoleh nilai 9,44 dengan persentase sebesar 94,38\% untuk $\mathrm{C} 1$, rat-rata nilai 5,99 dengan persentase sebesar $85,57 \%$ untuk C2 dan rata-rata nilai 5,63 dengan persentase sebesar 70,37\% untuk C3. Maka dari itu, hasil 
120 Jurnal PG-PAUD Trunojoyo : Jurnal Pendidikan dan Pembelajaran Anak Usia Dini, Volume 6, Nomor 2, Oktober 2019, hal 114 - 124, ISSN : 2528-3553 (online), ISSN: 2407-4454 (print)

penelitian untuk $\mathrm{C} 1, \mathrm{C} 2$ dan $\mathrm{C} 3$ berada pada kategori baik.

Berdasarkan analisis data diatas maka Tingkat Pengetahuan guru PAUD tentang Kurikulum 2013 di TK Se-Kecamatan Pademawu Kabupaten Pamekasan yaitu sebesar $87,71 \%$ yang artinya H_0 ditolak dan H_a diterima. Maka dari itu, dapat disimpulkan bahwa tingkat pengetahuan guru PAUD tentang kurikulum 2013 berada pada kategori baik.

\section{Pembahasan}

Berdasarkan deskripsi penelitian diketahui bahwa tingkat pengetahuan guru PAUD tentang Kurikulum 2013 di TK sekecamatan Pademawu Kabupaten Pamekasan berada pada kategori baik dengan persentase sebesar $87,71 \%$.

Pada penelitian ini pengetahuan diartikan sebagai hasil ilmu yang didapat seseorang setelah orang tersebut mengetahui melalui indera berdasarkan apa yang terjadi. Seorang guru dalam mengelola pendidikan dituntut untuk mempunyai pengetahuan yang baik dalam pembelajaran. Melalui kurikulum 2013 guru dapat memberikan kontribusinya, dalam hal ini diharapkan guru mampu untuk memperbaiki pembelajaran yang lebih baik. Pengetahuan yang baik pada guru dapat memberikan kualitas yang baik pula pada peserta didik. Setiap guru memiliki tingkat pengetahuan yang berbeda-beda karena pengalaman yang didapatkan berbeda-beda pula.

Pengetahuan adalah sebagai suatu pembentukan yang terus-menerus oleh seseorang yang setiap saat mengalami reorganisasi karena adanya pemahamanpemahaman baru (Budiman \& Riyanto, 2013: 4) Oleh karena itu, setelah seseorang mempelajari sesuatu maka akan tersimpan di dalam memori otak dan hal tersebut disebut dengan pengetahuan. Pendapat lain tentang pengetahuan diungkapkan oleh Notoatmodjo, "pengetahuan adalah hasil penginderaan manusia, atau hasil tahu sesorang terhadap objek melalui indra yang dimilikinya (mata, hidung, telinga, dan sebagainya)" (Notoatmodjo, 2010: 27). Dengan kata lain, pengetahuan merupakan pendapat yang dimiliki seseorang melalui panca indera yang dimiliki sehingga menghasilkan temuan atau pengalaman baru. Melalui panca indera akan diperoleh pengetahuan, tergantung bagaimana seseorang menggunakan panca indera tersebut terhadap sesuatu yang dipelajari.

Hasil penelitian juga menunjukkan bahwa persentase tertinggi dalam penelitian yaitu $100 \%$ dengan butir soal sebanyak 25 dijawab dengan benar secara keseluruhan. Disamping itu persentase terendah diketahui sebesar 68\% dengan menjawab butir soal benar sebanyak 17 butir secara keseluruhan. Berdasarkan paparan diatas diketahui bahwa tingkat pengetahuan yang didapat guru berbeda-beda. Hal tersebut disebabkan karena pengalaman, usia dan tingkat pendidikan yang berbeda. Perbedaan pengetahuan disebabkan karena beberapa faktor seperti pendidikan, informasi/media massa, lingkungan, pengalaman dan usia (Budiman \& Riyanto, 2013: 4). Maka dari itu, tidak heran jika pengetahuan guru PAUD yang berada di TK Kecamatan Pademawu Kabupaten Pamekasan menjawab pernyataan pada lembar tes yang telah diberikan oleh peneliti berbeda-beda dan skor yang diperoleh berbeda pula.

Diketahui bahwa guru yang peneliti jadikan sampel rata-rata berijazah SMA dan S1. Menurut Budiman dan Riyanto, pengetahuan sangat erat kaitannya dengan pendidikan, semakin tinggi pendidikan seseorang maka semakin luas pengetahuannya. Namun, perlu diketahui bahwa seseorang yang berpendidikan rendah tidak berarti mutlak berpengetahuan rendah pula (Budiman \& Riyanto, 2013: 5). Maka dari itu walaupun perbedaan tingkat pendidikan tidak berpengaruh terhadap tingkat pengetahuan. Hal tersebut terbukti dari penelitian yang dilakukan oleh peneliti bahwa tingkat pengetahuan guru PAUD tentang Kurikulum 2013 di TK Se-Kecamatan Pademawu Kabupaten Pamekasan tetap berada pada kategori baik. Faktor tersebut disebabkan karena pengalaman yang diperoleh setiap guru berbeda.

Pengalaman merupakan teman yang baik bagi seseorang untuk berproses menjadi lebih baik lagi. Menurut Budiman dan Riyanto, pengalaman sebagai sumber pengetahuan merupakan suatu cara untuk memperoleh kebenaran pengetahuan dengan cara mengulang kembali pengetahuan yang diperoleh (Budiman \& Riyanto, 2013: 6). Semakin lama guru tersebut mengajar dan mengelola lembaga TK serta pelatihanpelatihan yang diikuti maka semakin banyak pula pengalaman yang akan didapat. Hal itu 
Jurnal PG-PAUD Trunojoyo : Jurnal Pendidikan dan Pembelajaran Anak Usia Dini, Volume 6, Nomor 2, Oktober 2019, hal 114 - 124, ISSN : 2528-3553 (online), ISSN: 2407-4454 (print)

tidak menutup kemungkinan bahwa guru yang pendidikannya lebih rendah memiliki tingkat pengetahuan yang lebih tinggi karena pengalaman selama di lapangan lebih banyak dan lebih lama.

Selain faktor pendidikan mempengaruhi tingkat pengetahuan, faktor usia juga mempengaruhi tingkat pengetahuan seseorang. Menurut Budiman dan Riyanto, semakin bertambah usia akan semakin berkembang pula daya tangkap dan pola pikirnya sehingga pengetahuan yang diperoleh semakin membaik (Budiman \& Riyanto, 2013: 6). Hal tersebut bertolak belakang dari penelitian yang dilakukan oleh peneliti di TK Kecamatan Pademawu Kabupaten Pamekasan. Semakin bertambah usia maka semakin menurun tingkat pengetahuaan. Kurikulum 2013 yang telah dilaksanakan di TK Kecamatan Pademawu Kabupaten Pamekasan sejak tahun 2014 membutuhkan guru-guru yang paham dengan teknologi canggih karena tuntutan perubahan zaman, sehingga guru-guru yang berusia lanjut merasa bahwa dirinya kurang dalam hal teknologi. Setelah peneliti melakukan penelitian lanjut ternyata informasi/media massa yang mempengaruhi juga terhadap perbedaan tingkat pengetahuan.

Saat ini tidak bisa dipungkiri bahwa informasi begitu dengan mudahnya diperoleh hanya dengan menggunakan smartphone. Menurut Budiman dan Riyanto, informasi merupakan sesuatu yang dapat diketahui. Informasi dapat dijumpai dalam kehidupan sehari-hari yang diperoleh dari data dan pengamatan terhadap dunia sekitar dan diteruskan melalui komunikasi (Budiman \& Riyanto, 2013: 5). Penggunaan alat komunikasi yang semakin canggih membuat seseorang mendapatkan informasi lebih cepat dan akurat tanpa harus menunggu koran dan surat kabar.

Pada penelitian ini peneliti melakukan wawancara kepada 5 orang. Guru PAUD yang dijadikan narasumber yaitu 1 orang guru dari 5 lembaga TK di Kecamatan Pademawu Kabupaten Pamekasan. Lembaga-lembaga yang bersedia untuk diwawancarai yaitu TK Al-Quran Muballighin dengan narasumber Ibu Winarni, TK Muslimat NU V dengan narasumber Ibu Supatmi, TK Nurul Iman dengan narasumber Ibu Mardiana, TK Dharma Wanita Sumedangan dengan narasumber Ibu Sufiyana dan TK Kartika Bartim dengan narasumber Ibu Eli. Peneliti hanya menggunakan 5 orang guru dalam penelitian ini karena keterbatasan waktu yang dilakukan peneliti dan terhalangnya kegiatan-kegiatan yang ada di setiap lembaga TK. Sehingga narasumber yang peneliti digunakan hanya sebanyak 5 orang.

Berdasarkan hasil wawancara yang telah dilakukan kepada lima lembaga TK, diketahui bahwa kurikulum 2013 merupakan kurikulum yang ditetapkan pemerintah untuk menggantikan kurikulum sebelumnya yaitu KTSP. Kurikulum 2013 dianggap sebagai kurikulum baru yang dalam upaya penerapannya dituntut untuk mengikuti perkembangan zaman. Dalam wawancara yang dilakukan, dari 5 orang guru yang diwawancarai mengungkapkan bahwa kurikulum 2013 sampai saat ini berjalan dengan baik walaupun ada beberapa kendala yang harus dihadapi. Kendala yang dihadapi dalam mengimplementasikan kurikulum 2013 yaitu karena tuntutan orang tua agar anaknya bisa membaca, menulis dan berhitung (calistung). Hal tersebut berdasarkan pada hasil wawancara dengan guru PAUD di TK Al-Quran Muballighin. Padahal seharusnya pembelajaran pada anak usia dini menyenangkan. Disamping itu, menurut Ibu Supatmi dengan adanya kurikulum 2013 sangat membantu pertumbuhan dan perkembangan peserta didik di lembaga TK Muslimat NU V.

Kendala lain yang dihadapi oleh guru PAUD di TK Kecamatan Pademawu Kabupaten Pamekasan terkait kurikulum 2013 yaitu dari pendidik sendiri, karena satu sekolah terkadang hanya mengandalkan satu orang untuk mengelola pembelajaran sehingga yang lainnya hanya mengikuti perintah dari guru yang bersangkutan. Sehingga hal tersebut menjadi kendala bagi TK untuk menerapkan kurikulum 2013 dengan sebaik mungkin. Sejalan dengan hal tersebut, hasil penelitian yang dilakukan oleh (Lupi: 2017) mengungkapkan bahwa, yang paling banyak berperan dalam dalam pelaksanaan kurikulum 2013 adalah pendidik karena tingkat kreativitas pendidik akan mempengaruhi pelaksanaan pembelajaran. Oleh karena itu, sebagai guru sudah seharusnya meningkatkan terus kemampuannya karena peran guru yang begitu penting dalam pembelajaran. 
122 Jurnal PG-PAUD Trunojoyo : Jurnal Pendidikan dan Pembelajaran Anak Usia Dini, Volume 6, Nomor 2, Oktober 2019, hal 114 - 124, ISSN : 2528-3553 (online), ISSN: 2407-4454 (print)

Sebagian besar TK di Kecamatan telah menggunakan kurikulum 2013 dan dalam perencanaan pembelajaran telah mengacu pada kurikulum 2013. Menurut Kauffman perencanaan merupakan sebuah proyeksi tentang apa yang diperlukan dalam mencapai tujuan yang dapat bernilai (Asmaati, 2014: 1). Berdasarkan hasil wawancara yang dirangkum perencanaan merupakan suatu proses merumuskan suatu kegiatan pembelajaran yang dijadikan acuan guru untuk mengelola kegiatan belajar dan bermain untuk mendukung dalam proses pembelajaran. Beberapa kendala juga dihadapi saat penyusunan perencanaan yaitu kurang memahami benar seluk beluk dalam penyususnan RPP, minimnya penguasaan teknologi, dan media pembelajaran yang akan digunakan.

Guru-guru yang diwawancarai mengetahui bagaimana langkah-langkah membuat Promes, RPPM dan RPPH. Mulai dari menentukan KI dan KD hingga kegiatan yang akan dalam setiap program perencanaan pembelajaran. Walaupun ada beberapa hal yang belum dipahami dalam membuat perencanaan, guru-guru yang ada di TK Kecamatan Pademawu Kabupaten Pamekasan tidak berhenti untuk belajar dan terus mengikuti pelatihan-pelatihan yang diberikan oleh pemerintah setempat. Pelatihan-pelatihan yang pernah dilakukan seperti pelatihan tentang kurikulum 2013, pengembangan kurikulum 2013, proses penilaian kurikulum 2013, dan peningkatan kinerja guru.

Hasil wawancara juga menunjukkan bahwa dalam pelaksanaan Kurikulum 2013 masih lebih banyak berpusat pada guru. Padahal seharusnya, untuk pembelajaran kurikulum 2013 lebih berpusat pada anak. Anak diharuskan untuk membangun sendiri kemampuannya. Guru hanya memberikan stimulus untuk memacu ide, gagasan dan pikiran yang ada pada anak. Sejalan dengan hal tersebut, menurut Dirjen Pendidikan Anak Usia Dini dan Pendidikan Masyarakat dalam Pedoman Pengelolaan Pembelajaran PAUD salah satu pembelajaran yang baik bagi anak usia dini adalah pembelajaran dengan pendekatan saintifik, yaitu salah satu pendekatan dalam membangun cara berpikir agar anak memiliki kemampuan menalar yang diperoleh melalui proses mengamati sampai mengkomunikasikannya (Kemendikbud Dirjen PAUD \& Pendidikan Masyarakat, 2015: 3).
Maka dari itu, guru hanya memberikan stimulus untuk memacu kemampuan dalam diri anak sehingga anak dapat mengembangkan kemampuan dengan sendirinya.

Kegiatan pelaksanaan pembelajaran dalam kelas di TK yang ada di Kecamatan Pademawu Kabupaten Pamekasan lebih banyak menggunakan model pembelajaran kelompok. Saat peneliti melakukan wawancara tidak ada satupun TK yang menggunakan model pembelajaran sentra. Menurut guruguru yang telah diwawancarai, jika lembaga TK menggunakan model pembelajaran sentra akan memakan banyak biaya. Berbeda dengan penelitian yang dilakukan oleh (Fadlillah: 2018) bahwa, salah satu faktor pendukung dalam pelaksanaan pembelajaran berbasis kurikulum 2013 yaitu model pembealajaran sentra yang digunakan di TK IT Qurrota A'Yun. Maka dari itu, dengan model pembelajaran sentra dapat mendukung implementasi kurikulum 2013 PAUD yang memiliki ciri khas pembelajaran yang saintifik.

Dalam hal penilaian, berdasarkan wawancara dengan guru cara penilaian yang dilakukan berbeda-beda. Penilaian merupakan suatu kegiatan pengumpulan informasi dan pengolahan data untuk mengetahui tumbuh kembang anak setelah melakukan kegiatan pembelajaran (Suyadi dan Dahlia, 2017: 3). Penilaian yang dilakukan untuk mengetahui sejauh mana pertumbuhan dan perkembangan peserta didik saat di lembaga TK. Sebagian besar lembaga TK di Kecamatan Pademawu Kabupaten Pamekasan menggunakan penilaian dengan teknik ceklis dan hasil karya.

Ceklis yang digunakan menggunakan skala BB, MB, BSH dan BSB. Ceklis merupakan penilaian untuk menentukan status perkembangan anak pada akhir periode penilaian (Kemendikbud Dirjen PAUD \& Pendidikan Masyarakat, 2015: 5). Melalui ceklis, guru dapat memberikan dan menentukan setiap pertumbuhan dan perkembangan peserta didik saat di lembaga TK. Berdasarkan informasi dari wawancara catatan ceklis diisi tidak setiap hari, tetapi dilakukan satu minggu atau satu bulan sekali. Padahal seharusnya proses penilaian dilakukan saat kegiatan berlangsung di sekolah yaitu mulai dari anak datang sampai kegiatan berakhir dan pulang.

Teknik penilaian yang digunakan di TK Kecamatan Pademawu Kabupaten Pamekasan 
berupa hasil karya anak. Hasil karya adalah hasil karya dari anak yang diungkapkan melalui kerajinan, seni, dan prakarya (Kemendikbud Dirjen PAUD \& Pendidikan Masyarakat, 2015: 10). Melalui hasil karya, anak dapat menunjukkan tingkat perkembangan serta kemampuan yang ada pada dirinya. Hasil karya yang telah dibuat anak dapat guru tanyakan kepada anak agar anak dapat menjelaskan apa yang telah dibuatnya. Hasil karya anak biasanya ditempel di ruang kelas dan dijadikan satu dalam sebuah buku. Selain itu, hasil karya anak diizinkan untuk dibawa pulang.

Catatan anekdot banyak yang tidak menerapkan karena guru menganggap hal itu sangat tidak memungkinkan. Alasannya, karena waktu yang kurang memadai dan masih banyak yang harus dilakukan di sekolah. Catatan anekdot merupakan catatan yang jarang sekali digunakan di lembaga TK di Kecamatan Pademawu. Catatan ini menjelaskan secara rinci tentang kapan, dimana dan bagaimana kegiatan yang terjadi. Menurut Beaty, "catatan anekdot (anecdotal record) merupakan catatan narartif singkat yang menjelaskan terjadinya perilaku anak yang penting bagi pengamat" (Beaty, 2013: 27). Melalui catatan anekdot guru dapat mengetahui kegiatan yang pokok atau peristiwa yang terjadi pada hari itu juga. Berdasarkan paparan diatas dapat disimpulkan bahwa di TK Kecamatan Pademawu Kabupaten Pamekasan sebagian besar dalam penilaian menggunakan ceklis dan hasil karya.

Pada saat peneliti melakukan penelitian mulai dari uji coba instrumen sampai pengambilan data di TK Se-Kecamatan Pademawu Kabupaten Pamekasan beberapa kendala tentu dihadapi oleh peneliti. Kendala tersebut yaitu karena terhalangnya oleh kegiatan perlombaan yang ada di TK Kecamatan Pademawu Kabupaten Pamekasan. Perlombaan yang dilaksanakan oleh setiap lembaga TK menjadi kendala saat penelitian karena kepala sekolah dan guru tidak secara langsung mengisi lembar tes dan harus ditinggalkan untuk beberapa hari. Selain itu, peneliti juga merasa kesulitan saat akan menemui kepala lembaga, sehingga peneliti harus kembali kepada TK yang menjadi sampel penelitian.

Kendala lain yang dihadapi pada saat peneliti mengambil data menggunakan lembar tes yaitu keseriusan guru-guru dalam dalam pengisiannya karena responden dipengaruhi oleh kondisi yang berbeda-beda seperti lelah, susah, senang, gembira dan sebagainya. Keterbatasan waktu peneliti yang mendekati liburan puasa. Walaupun demikian, libur menjelang puasa hanya beberapa hari dan saat puasa sebagian besar lembaga tidak diliburkan. Oleh karena itu, peneliti dapat memanfaatkan waktu tersebut untuk menyebarkan lembar tes dan melakukan wawancara. Sehingga kendala yang dihadapi peneliti dalam pengambilan data tidak begitu sulit. Lokasi lembaga TK yang dijadikan penelitian cukup jauh. Setiap lokasi lembaga TK yang satu dengan lembaga TK yang lainnya memiliki jarak yang jauh pula.

\section{SIMPULAN}

Berdasarkan hasil penelitian diatas dapat disimpulkan bahwa tingkat pengetahuan guru PAUD tentang kurikulum 2013 di TK SeKecamatan Pademawu Kabupaten Pamekasan berada pada kategori baik persentase sebesar $87,71 \%$. Hasil penelitian pada faktor mengingat $(\mathrm{C} 1)$ sebagian besar berada pada kategori baik yaitu dengan persentase sebesar 94,38\%, mengerti (C2) sebagian besar berada pada kategori baik yaitu sebesar $85,57 \%$, dan mengaplikasikan (C3) yaitu sebesar 70,37\%. Hasil penelitian tersebut disimpulkan bahwa Tingkat Pengetahuan Guru PAUD tentang Kurikulum 2013 di TK Se-Kecamatan Pademawu Kabupaten Pamekasan adalah baik.

\section{SARAN}

Berdasarkan data hasil dan penelitian Tingkat Pengetahuan Guru PAUD tentang Kurikulum 2013 di TK Se-Kecamatan Pademawu Kabupaten Pamekasan hal-hal yang perlu peneliti sarankan sebagai berikut: (1) Bagi pemerintah dan pengawas lembaga TK, tetap mempertahankan dan meningkatkan lagi untuk mengadakan pelatihan-pelatihan, diklat dan kegiatan yang mendukung penerapan pembelajaran kurikulum 2013 kepada guru-guru; (2) Bagi guru dan pengelola lembaga, adanya upaya untuk mempertahankan dan meningkatkan kompetensi pedagogik tingkat pengetahuan tentang kurikulum 2013 yang meliputi perencanaan, pelaksanaan, penilaian dan evaluasi; dan (3) Bagi peneliti selanjutnya, perlu dilakukan penelitian lebih lanjut lagi 
124 Jurnal PG-PAUD Trunojoyo : Jurnal Pendidikan dan Pembelajaran Anak Usia Dini, Volume 6, Nomor 2, Oktober 2019, hal 114 - 124, ISSN : 2528-3553 (online), ISSN: 2407-4454 (print)

mengenai tingkat pengetahuan guru PAUD tentang kurikulum 2013 dan beberapa faktor lainnya yang mempengaruhi tingkat pengetahuan seperti usia dan tingkat pendidikan sebelumnya, sehingga hasilnya dapat memberikan acuan sebagai referensi peneliti selanjutnya.

\section{DAFTAR PUSTAKA}

Arifin, Z. 2014. Penelitian Pendidikan Metode dan Paradigma Baru. Bandung: PT Remaja Rosdakarya.

2016. Evaluasi Pembelajaran. Bandung: PT Remaja Rosdakarya.

Asmani, J. M. 2015. Panduan Praktis Manajemen Mutu Guru PAUD. Yogyakarta: Diva Press.

Asmawati, L. 2014. Perencanaan Pembelajaran PAUD. Bandung: PT Remaja Rosdakarya.

Beaty, J. J. Observasi Perkembangan Anak Usia Dini. Terjemahan Arif Rakhman. 2013. Jakarta: Kencana Prenadamedia Group.

Budiman \& Riyanto, A. 2013. Kapita Selekta Kuesioner: Pengetahuan dan Sikap dalam Penelitian Kesehatan. Jakarta: Salemba Medika.

Dirjen Pendidikan Anak Usia Dini dan Pendidikan Masyarakat. 2015. Kurikulum Pendidikan Anak Usia Dini Apa, Mengapa dan Bagaimana. Jakarta: Direktorat Pembinaan Pendidikan Anak Usia Dini 2015. Pengelolaan Pembelajaran Pendidikan Anak Usia Dini. Jakarta: Direktorat Pembinaan Pendidikan Anak Usia Dini

2015. Penilaian Pembelajaran Pendidikan Anak Usia Dini. Jakarta: Direktorat Pembinaan Pendidikan Anak Usia Dini

2015. Penyusunan Rencana Pelaksanaan Pembelajaran Pendidikan Anak Usia Dini. Jakarta: Direktorat Pembinaan Pendidikan Anak Usia Dini

Fadlillah, M. 2018. Pelaksanaan Pembelajaran Berbasis Kurikulum 2013 di TK IT Qurrota A'Yun Babadab Ponorogo. Jurnal Pendidikan: Early Childhood, Volume 2 (1): 10

Lupi, N. Z. N. 2017. Problematika Penerapan Kurikulum 2013 pada Lembaga
Pendidikan Anak Usia Dini di Kecamatan Bululawang. Jurnal PGPAUD Trunojoyo, Vol. 4 (1): 1-81

Mulyasa. 2015. Pengembangan dan Implementasi Kurikulum 2013. Bandung: PT Remaja Rosdakarya.

Musfah, J. 2011. Peningkatan Kompetensi Guru: Melalui Pelatihan dan Sumber Belajar Teori dan Praktik. Jakarta: Prenada Media Group

Naim, N. 2016. Menjadi Guru Inspiratif Memberdayakan dan Mengubah Jalan Hidup Siswa. Yogyakarta: Pustaka Pelajar

Notoatmodjo, S. 2010. Ilmu Perilaku Kesehatan. Jakarta: PT Rineka Cipta

Peraturan Menteri Pendidikan dan Kebudayaan Republik Indonesia Nomor 137 Tahun 2014 tentang Standar Nasional Pendidikan Anak Usia Dini.

Peraturan Menteri Pendidikan dan Kebudayaan Republik Indonesia Nomor 146 Tahun 2014 tentang Kurikulum 2013 Pendidikan Anak Usia Dini.

Rahelly, Y. 2018. Implementasi Kurikulum 2013 Pendidikan Anak Usia Dini (PAUD) di Sumatera Selatan. Jurnal Pendidikan Anak Usia Dini, Vol. 12 (2): $381-390$

Sugiyono. 2015. Metode Penelitian Pendidikan (Pendekatan Kuantitatif, Kualitatif dan $R \& D$. Bandung: Alfabeta.

Supardi. 2013. Aplikasi Statistika dalam Penelitian Edisi Revisi Konsep Statistika yang Lebih Komprehensif. Jakarta: Change Publication.

Supratiningrum, J. 2016. Guru Profesional: Pedoman Kinerja, Kualifikasi \& Kompetensi Guru. Yogyakarta: ArRuz Media.

Suyadi \& Dahlia. 2017. Implementasi Kurikulum dan Inovasi Kurikulum 201

Program Pembelajaran Berbasis Multiple Intelligences. Bandung: PT Remaja Rosdakarya.

Undang-Undang Republik Indonesia Nomor 20 Tahun 2003 tentang Sistem Pendidikan Nasional. Bandung: Wacana Adhtya. 